\title{
HUBUNGAN PENGETAHUAN DAN PERILAKU PERAWAT DALAM MENERAPKAN KESEHATAN DAN KESELAMATAN KERJA (K3) DALAM KEPERAWATAN
}

\author{
Khairun Nisa Ginting
}

\author{
Kahirunnisaginting06@gmail.com
}

\section{LATAR BELAKANG}

Kesehatan dan Keselamatan Kerja (K3) merupakan suatu upaya perlindungan kepada tenaga kerja dan orang lain yang memasuki tempat kerja terhadap bahaya dari akibat kecelakaan kerja. Tujuan K3 adalah mencegah, megurangi, bahkan menihilkan resiko penyakit dan kecelakaan akibat kerja (KAK) serta meningkatkan derajat kesehatan para pekerja sehingga produktivitas kerja meningkat. Dalam Undang-Undang Republik Indonesia Nomor 36 Tahun 2009 Tentang Kesehatan, upaya kesehatan kerja ditunjukkan untuk melindungi pekerja agar hidup sehat dan terbebas dari gangguan kesehatan serta pengaruh buruk yang diakibatkan oleh pekerjaan sehingga sudah seharusnya pihak pengelola RS menerapkan upaya-upaya K3 di RS. K3 termasuk sebagai salah satu standar pelayanan yang dinilai di dalam akreditasi RS, disamping standar pelayanan lainnya.

Upaya penerapan K3 di rumah sakit menyangkut tenaga kerja, cara/metode kerja, alat kerja, proses kerja, dan lingkungan kerja yang meliputi peningkatan, pencegahan, pengobatan, dan pemulihan.26,27 Tenaga kesehatan yang sering berkontak langsung dengan pasien adalah perawat. Tingkat pengetahuan K3 perawat sangat penting dalam menjaga keselamatan pasien dan diri perawat itu sendiri sesuai dengan penelitian terdahulu bahwa didapatkannya hubungan bermakna antara tingkat pengetahuan perawat dengan tindakan keselamatan terhadap pasien

Kesehatan dan keselamatan kerja merupakan salah satu isu penting di dunia kerja saat ini. Hasil riset yang di lakukan oleh badan dunia ILO menyebutkan bahwa setiap hari rata-rata 6.000 
orang meninggal, setara dengan satu orang setiap 15 detik atau 2,2 juta orang per tahun akibat sakit atau kecelakaan yang berkaitan dengan pekerjaannya (Rahayuningsih \& Hariyono, 2011).

Kecelakaan kerja menjadi salah satu masalah urgen di lingkungan rumah sakit. Hal ini diakibatkan karena rumah sakit merupakan suatu unit pelayanan kesehatan yang memberikan pelayanan pada semua bidang dan jenis penyakit. Oleh sebab itu rumah sakit dituntut untuk dapat menyediakan dan menerapkan suatu upaya agar semua sumber daya manusia yang ada di rumah sakit dapat terlindungi, baik dari penyakit maupun kecelakaan akibat kerja (Ivana, Widjasena \& Jayanti, 2014). Pemerintah melakukan berbagai upaya untuk mengatasi kecelakaan kerja di rumah sakit, salah satunya dengan dikeluarkannya Undang-Undang Nomor 23 Tahun 1992 dan Undang-Undang Nomor 36 Tahun 2009 tentang penerapan Kesehatan dan Keselamatan Kerja di rumah sakit (Kepmenkes RI, 2010, p.8)

\section{METODE}

Metode yang digunakan adalah metode kualitatif dimana maksudnya dengan cara mengumpulkan sebanyak-banyaknya data untuk dianalisis. Yaitu dengan Literature review ini dengan menganalisis yang berfokus pada pentingnya implementasi keperawatan dalam mengoptimalkan asuhan keperawatan. Adapun tinjauan literatur yang digunakan seperti buku teks, buku referensi, jurnal, dan google scholar. Dengan kata kunci Pentingnya Implementasi, Asuhan Keperawatan, Implementasi keperawatan. Dan literature yang digunakan adalah 14 literatur yang diterbitkan 10 tahun terakhir.

\section{HASIL}

Berdasarkan Indonesian Journal of Public Health and Community Medicine Vol. 1, No. 3 Juli 2020 mengatakan bahwa Pencegahan kecelakaan kerja dapat dilakukan dengan (1) pengamatan resiko bahaya di tempat kerja, (2) pelaksanaan SOP secara benar di tempat kerja, (3) pengendalian faktor bahaya di tempat kerja, (4) peningkatan pengetahuan tenaga kerja terhadap keselamatan kerja dan (5) pemasangan peringatan bahaya kecelakaan di tempat kerja. Selain itu upaya pencegahan kecelakaan kerja juga perlu disediakan sarana untuk menanggulangi kecelakaan di tempat kerja seperti penyediaan P3K, penyediaan peralatan dan perlengkapan tanggap darurat (Cecep, 2014). pengetahuan yang kurang baik terhadap penerapan manajemen K3 rumah sakit memounyai risiko sebesar 8 kali dibandingan dengan pengetahuan yang baik. 
Jika setiap pekereja mempunyai pengetahuan yang baik terhadap penerapan K3 rumah sakit, maka risiko terjedainya penyakit akibat kerja dan kecelakaan akibat kerja akan terhindar atau berkurang

Berdasarkan Idea Nursing Journal Vol. VIII No. 32017 mengatakan bahwa Dalam penelitian di Thailand, terdapat hubungan yang signifikan antara sikap perawat terhadap pencegahan cidera/ kecelakaan akibat benda tajam dan terjadinya cidera akibat benda tajam. Perawat yang memiliki sikap negative terhadap pencegahan cidera benda tajam hampir dua kali cenderung terkena cidera benda tajam dibandingkan dengan yang bersikap positif. Rumah sakit dapat mengurangi jumlah kejadian tertusuk benda tajam dengan meningkatkan sikap perawat dimana sikap sangat berhubungan dengan perilaku. bahwa sikap ada hubungan dengan kejadian kecelakaan kerja. Dan bahwa sikap yang kurang memberikan responden terhadap penerapan K3 rumah sakit mempunyai peluang sebesar 8 kali dapat menyebabkan kecelakaan kerja dibandingankan dengan sikap yang baik. Bagi setiap petugas rumah sakit agar mempunyai sikap yang baik terhadap penerapan K3 rumah sakit agar kecelakaan akibat kerja dan penyakit akibat kerja dapat dikurangi

\section{PEMBAHASAN}

Semua faktor yang dapat menentukan atau membentuk perilaku manusia disebut determinan perilaku. Determinan perilaku manusia terdiri dari faktor internal dan faktor eksternal. Faktor internal yaitu karakteristik dari individu yang bersangkutan yang bersifat bawaan sedangkan faktor eksternal yaitu faktor yang berasal dari luar diri seseorang (Notoatmodjo, 2010). Berdasarkan asumsi peneliti ada berbagai faktor yang dapat mempengaruhi perilaku perawat ditinjau dari faktor internal berada pada kategori baik, diantaranya persepsi. Persepsi merupakan suatu proses pencarian informasi yang dilakukan oleh perawat sebelum melakukan suatu tindakan.

Persepsi perawat tentang K3 menunjukkan bagaimana perawat mampu mencari tahu tentang pentingnya K3 baik melalui brosur, leaflet, SOP yang disediakan di ruangan maupun media informasi lainnya. Perawat juga dituntut untuk faham bagaimana cara pencegahan

kecelakaan serta penanganan yang dapat dilakukan apabila kecelakaan terjadi. Pemahaman tersebut akan menimbulkan persepsi yang baik dalam diri perawat tentang K3 sehingga hal ini 
akan meningkatkan perilakunya dalam menjaga keselamatan. faktor motivasi dan persepsi dapat mempengaruhi kepatuhan perawat dalam pelaksanaan asuhan keperawatan yang sesuai dengan SOP. Perawat dengan persepsi baik memiliki kemungkinan lebih besar untuk patuh dibandingkan dengan perawat dengan persepsi kurang. Selain persepsi, sikap juga mempengaruhi perilaku perawat ditinjau dari segi faktor internal (Notoadmodjo, 2010).

Seorang perawat dalam melaksanakan manajemen K3 harus memiliki sikap yang sesuai dengan nilai-nilai kesehatan dimana seluruh nilai positif yang ada dalam dirinya menjadi pendorong perilaku sehat dan menjadi upaya dalam meningkatkan kesehatan dan keselamatan selama bekerja. Selain itu, Notoadmodjo (2010) menambahkan bahwa ada berbagai cara yang dapat dilakukan untuk meningkatkan persepsi, pengetahuan dan sikap perawat dalam menjaga kesehatan dan keselamatan selama bekerja, diantaranya dengan memberikan promosi kesehatan dan pelatihan tentang K3 sehingga hal ini diharapkan mampu merubah perilaku perawat menjadi lebih baik.

Selain faktor internal, faktor eksternal juga sangat mempengaruhi perilaku perawat dalam penerapan manajemen K3 di rumah sakit. Peneliti berasumsi bahwa ada banyak faktor yang dapat menentukan perubahan perilaku perawat dari segi faktor eksternal, diantaranya pengalaman. Pengalaman perawat dapat dilihat dari berbagai aspek. Salah satunya adalah masa kerja. Semakin lama masa kerja perawat maka pengalaman yang dimiliki juga semakin meningkat sehingga perilakunya dalam menjaga keselamatan dirinya juga menjadi lebih baik. Selain itu pengalaman juga dapat diperoleh dari berbagai sosialisasi maupun pelatihan tentang K3 yang dilakukan oleh pihak rumah sakit.

Faktor selanjutnya yang ikut berperan dalam perubahan perilaku perawat yaitu tersedianya fasilitas yang mendukung sesuai dengan standar yang telah ditentukan. Nilai yang paling tinggi pada faktor enabling berada pada komponen hukum/aturan, artinya secara umum perilaku seseorang dipengaruhi oleh aturan yang ada di lingkungannya. Selain beberapa faktor diatas, budaya organisasi juga berpengaruh terhadap perilaku perawat dalam melaksanakan keselamatan, dimana budaya organisasi yang baik akan mendorong perawat untuk bekerja sesuai dengan prosedur yang telah ditetentukan (Notoadmodjo, 2010). determinan perilaku perawat dalam melaksanakan keselamatan pasien yang menunjukkan adanya hubungan yang signifikan antara budaya organisasi dengan perilaku perawat dalam menjaga keselamatan. Budaya 
organisasi yang baik mempunyai peluang 2,652 kali lebih besar untuk mempunyai perilaku yang lebih baik dalam meningkatkan keselamatan selama bekerja.

Berdasarkan hasil penelitian ini peneliti berasumsi bahwa perilaku perawat dalam penerapan manajemen Kesehatan dan Keselamatan Kerja (K3) ditinjau dari faktor internal dan ekternal berada pada kategori baik karena berbagai alasan, diantaranya: komite Kesehatan dan Keselamatan Kerja Rumah Sakit (K3RS) sudah melakukan fungsi manajeman K3RS dengan baik, seperti dilakukannya promosi kesehatan dan pelatihan tentang K3. Selain itu sebagian besar perawat juga sudah memiliki pengalaman dan pengetahuan yang baik tentang penerapan K3, fasilitas yang disediakan serta budaya organisasi yang ada di rumah sakit sudah mengacu pada standar yang telah ditentukan sesuai dengan peraturan KEPMENKES RI 2010 dan peran dari rumah sakit khususnya kepala ruang juga sudah berfungsi secara optimal dalam melakukan monitoring dan evaluasi terhadap kinerja perawat dalam menerapkan budaya Kesehatan dan Keselamatan Kerja (K3).

Hubungan sikap terhadap penerapan manajemen K3RS Dalam penelitian di Thailand, terdapat hubungan yang signifikan antara sikap perawat terhadap pencegahan cidera/ kecelakaan akibat benda tajam dan terjadinya cidera akibat benda tajam. Perawat yang memiliki sikap negative terhadap pencegahan cidera benda tajam hampir dua kali cenderung terkena cidera benda tajam dibandingkan dengan yang bersikap positif. Rumah sakit dapat mengurangi jumlah kejadian tertusuk benda tajam dengan meningkatkan sikap perawat dimana sikap sangat berhubungan dengan perilaku. sikap ada hubungan dengan kejadian kecelakaan kerja. sikap yang kurang memberikan responden terhadap penerapan K3 rumah sakit mempunyai peluang sebesar 8 kali dapat menyebabkan kecelakaan kerja dibandingankan dengan sikap yang baik.

Bagi setiap petugas rumah sakit agar mempunyai sikap yang baik terhadap penerapan K3 rumah sakit agar kecelakaan akibat kerja dan penyakit akibat kerja dapat dikurangi. Melihat masih ada perawat atau petugas rumah sakit yang tidak melakukan penerapan manajemen K3 rumah sakit. Oleh karena itu direkomendasikan kepada perawat dan semua petugas di rumah sakit untuk bersikap positif terhadap prosedur pelaksanaan keselamatan dan kesehatan kerja dalam bentuk mendukung/ menyetujui segala program K3 khususnya untuk pencegahan kecelakaan kerja maka diusahakan adanya sikap yang pro aktif untuk mengaplikasikan ilmu baru tentang pelaksanaan keselamatan dan kesehatan kerja. Semakin pro aktif mengaplikasikan ilmu 
baru maka akan semakin bersikap positif tentang pelaksanaan $\mathrm{K} 3$ sehingga akan mengurangi kejadian kecelakaan kerja. Atas dasar rekomendasi diatas maka perlu adanya peran serta Rumah Sakit khususnya bagian Komite K3RS untuk memberikan informasi dan ketetapan standar operasional prosedur yang sesuai dengan pelaksanaan K3 secara bertahap dan menyeluruh.

Hubungan pengetahuan terhadap penerapan manajemen K3RS Pencegahan kecelakaan kerja dapat dilakukan dengan (1) pengamatan resiko bahaya di tempat kerja, (2) pelaksanaan SOP secara benar di tempat kerja, (3) pengendalian faktor bahaya di tempat kerja, (4) peningkatan pengetahuan tenaga kerja terhadap keselamatan kerja dan (5) pemasangan peringatan bahaya kecelakaan di tempat kerja. Selain itu upaya pencegahan kecelakaan kerja juga perlu disediakan sarana untuk menanggulangi kecelakaan di tempat kerja seperti penyediaan P3K, penyediaan peralatan dan perlengkapan tanggap darurat (Cecep, 2014).

Setiap tindakan yang dilakukan oleh perawat mempunyai potensi bahaya berupa bahaya fisik, biologi, dan ergonomi. Bahaya fisik didapatkan pada pekerjaan yang menggunakan alat yang tajam, seperti memasang infus dan menjahit luka. Bahaya biologi terdapat pada tindakan invasif, merawat luka, memasang infuse, dan memberikan obat melalui rektal. Sedangkan postur janggal ketika membungkuk merupakan bahaya pekerjaan karena faktor ergonomi.

\section{PENUTUP}

penerapan K3RS secara keseluruhan melibatkan perawat dalam meningkatkan kualitas keamanan dan kenyamanan pasien selama di rawat di Rumah Sakit. Penerapan K3RS tentunya ditetapkan kebijakan oleh pihak Rumah Sakit sesuai dengan peraturan perundang undangan yang berlaku. Dan terdapat hubungan antara faktor psikologi dan perilaku serta pengetahuan perawat dalam penerapan K3RS di RSU demi menjaga keselamatan pasien dalam keselamatan tim kesehatan yaitu perawat 


\section{DAFTAR PUSTAKA}

Cecep Dani Sucipto. .(2014) Keselamatan dan Kesehatan Kerja, Gosyen Publising: Yogjakarta.

Ernawati, N., \& Nurlelawati, E. (2017). Faktor-Faktor Yang Berhubungan Dengan Pelaksanaan Penerapan K3 Pada Tenaga Kesehatan di RSIA Permata Sarana Husada Periode Februari 2015. Jurnal Akademi Keperawatan Husada Karya Jaya, 3(1).

Ivana, A., Widjasena, B., \& Jayanti, S. (2014). Analisa Komitmen Manajemen Rumah Sakit (RS) terhadap Keselamatan dan Kesehatan Kerja (K3) pada RS Prima Medika Pemalang. Jurnal Kesehatan Masyarakat (e-Journal), 2(1), 35-41.

Ivana, A., Widjasena, B., \&Jayanti, S. (2014). Analisa Komitmen Rumah Sakit (RS) Terhadap Keselamatan Dan Kesehatan Kerja (K3) Pada RS Prima Medika Pemalang, Volume 2, Nomor 1, Hal 35-41.

Mandey, sylvia. dkk. (2020). Faktok psikologi dan perilaku dengan penerapan manajemen keselamatan dan kesehatan kerja rumah sakit. Indonesian Journal of Public Health and Community Medicine Volume 1 Nomor 3

Natasia, N., Loekqijana, A., \& Kurniawati, J. (2014). Faktor yang Mempengaruhi Kepatuhan Pelaksanaan SOP Asuhan Keperawatan di ICU -ICCU RSUD Gambiran Kota Kediri . Jurnal Kedokteran Brawijaya, Vol. 28, Suplemen No. 1.

Nazirah , riska.dkk. (2017). Perilaku perawat dalam penerapan manajemen kesehatan dan keselamatan kerja (k3) di aceh. Idea Nursing Journal Vol. VIII No. 32017 ISSN : 20872879, e-ISSN : $2580-2445$

Runtu, L. G., Haryanti, F., \& Rahayujati, T. B. (2013). Faktor-Faktor yang Berhubungan dengan Perilaku Perawat dalam Penerapan Universal Precautions di RSUP Prof. Dr. RD Kandou Manado. Jurnal Ilmiah Perawat Manado (Juiperdo), 2(1).

Salawati L, Herry N, Putra A.(2014). Analisis tindakan keselamatan dan kesehatan kerja perawat dalam pengendalian infeksi nosokomial di ruang ICU RSUD DR.Zainoel Abidin Banda Aceh. J Kedokt Syiah Kuala. 14(3):128-34.

Simamora, R. H. (2018). Buku ajar keselamatan pasien melalui timbang terima pasien berbasis komunikasi efektif: SBAR. Medan: USUpress.

Simamora, R. H. (2019). Buku ajar pelaksanaan identifikasi pasien. Uwais Inspirasi Indonesia.

Tukatman., Sulistiawati., Purwaningsih., \& Nursalam. (2015). Analisis Keselamatan Dan Kesehatan Kerja Perawat Dalam Penanganan Pasien Di Rumah Sakit Benyamin Guluh Kabupaten Kolaka. Jurnal Ners Vol. 10 No. 2. 